\title{
Een patiënt met een grote niertumor: niet altijd voor de uroloog
}

\author{
Maud A. S. Weerink ${ }^{1} \cdot$ Marcel Nijland $^{1} \cdot$ Igle J. de Jong $^{1} \cdot$ Annemarie Leliveld $^{1}$
}

Published online: 14 October 2016

(C) The Author(s) 2016. This article is available at SpringerLink with Open Access.

Samenvatting Een 68-jarige patiënt presenteerde zich met flankpijn ten gevolge van een grote renale massa. Onder verdenking van een renaalcelcarcinoom werd een nefrectomie verricht. Pathologisch onderzoek toonde een diffuus grootcellig B-cellymfoom. Primair renale manifestatie van een lymfoom komt weinig voor. De diagnose wordt vaak gemist of pas gesteld na het verrichten van een nefrectomie. Een primair renaal lymfoom moet overwogen worden als er radiologisch sprake is van een hypovasculair, diffuus groeiend proces, waarbij de voor renaalcelcarcinoom kenmerkende calcificaties en vasculaire tumorinvasie ontbreken. Indien histologisch bewezen, kan curatieve behandeling middels chemo-immunotherapie gestart worden.

In dit artikel worden de diagnostische overwegingen en kenmerken van een renaal lymfoom besproken.

Trefwoorden renaalcelcarcinoom $\cdot$ primair renaal lymfoom $\cdot$ nierbiopt

\section{A patient with a large renal tumor: not always for the urologist}

Abstract A 68-year old patient presented with flank pain caused by a large renal mass. A nephrectomy was performed because renal cell carcinoma was suspected. Pathological examination showed a diffuse large B-cell lymphoma. Primary renal manifestation of a lymphoma is rare. The diagnosis is often missed or only recognized after

drs. Maud A. S. Weerink

maudweerink@gmail.com

1 afdeling Urologie, Universitair Medisch Centrum Groningen, Groningen, Nederland a nephrectomy is performed. A primary renal lymphoma must be considered when radiologically a hypovascular, diffuse growing process is seen, without the characteristic signs of renal cell carcinoma, like calcifications and vascular invasion. Diagnosis can be confirmed by biopsies and, once histologically proven, curative treatment with chemoimmunotherapy is possible.

In this article the diagnostic considerations and characteristics of a renal lymphoma are described.

Keywords renal cell carcinoma $\cdot$ primary renal lymphoma $\cdot$ renal biopsy

\section{Introductie}

Niertumoren worden vaak per toeval ontdekt en kunnen lang asymptomatisch blijven. Minder dan $10 \%$ van de patiënten presenteert zich met de klassieke trias van flankpijn, een palpabele massa en hematurie. Van de solide niertumoren is $80-85 \%$ een renaalcelcarcinoom (RCC) en ongeveer $8 \%$ een urotheelcelcarcinoom (UCC) [1]. Radiologische kenmerken, zoals hypovasculariteit, diffuse groei, slechte aankleuring na intraveneuze contrasttoediening en het ontbreken van calcificaties, zijn atypisch voor een renaalcelcarcinoom en kunnen in de richting van een lymfoom wijzen. Als de presentatie op de CT-scan atypisch is voor een renaalcelcarcinoom, dient men biopten te overwegen, teneinde een diagnose te kunnen stellen. In deze casus beschrijven we een patiënt met een grote renale massa die op de CT-scan atypisch is voor een renaalcelcarcinoom. 


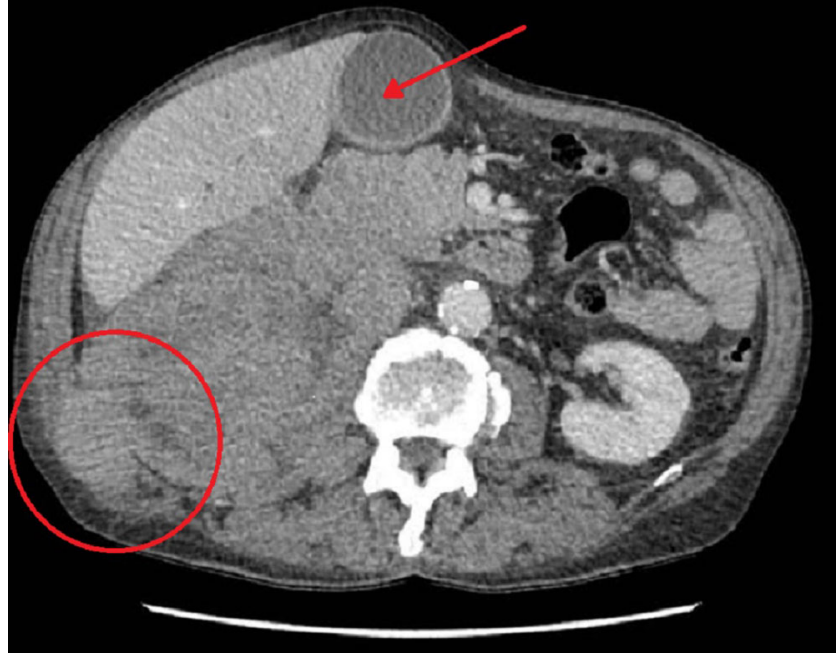

Figuur 1 CT-scan van patiënt A. Er is een diffuus infiltratief groeiend tumorproces te zien, met perirenale groei, ingroei in de rechterleverkwab en ingroei in de laterodorsale thoraxwand ( cirkel). Tevens is er een hydrops van de galblaas zichtbaar (pijl).

\section{Casus}

Patiënt $\mathrm{A}$, een 68-jarige vitale man met een blanco voorgeschiedenis, meldde zich bij de huisarts met sinds twee maanden pijn in zijn rechterflank, een opgezette buik en fors nachtzweten. Hij had geen mictie- of defecatieklachten, geen hematurie en was niet afgevallen. Het abdomen was bol, met in de rechterflank een zichtbare, vast aanvoelende zwelling. Een echografie toonde een groot tumorproces, uitgaande van de rechternier, met tekenen van tumorinfiltratie van de lever en galwegobstructie. Bij laboratoriumonderzoek werd een milde anemie van $6,5 \mathrm{~mol} / \mathrm{l}$ $(N: 8,7-10,6 \mathrm{~mol} / \mathrm{l})$, cholestatisch gestoorde leverenzymen en een verhoogde LDH-spiegel van $371 \mathrm{U} / 1$ ( $N$ : 0-250 U/l) gevonden. De nierfunctie was ongestoord. In het urinesediment werd een microscopische hematurie vastgesteld, maar cytologisch onderzoek liet geen voor maligniteit verdachte cellen zien. Een CT-thorax/abdomen (fig. 1) toonde een diffuus infiltratief groeiend tumorproces, met perirenale groei, ingroei in de rechterleverkwab en ingroei in de laterodorsale thoraxwand. Initieel werd gedacht aan een RCC, UCC dan wel een sarcoom. Mediaal van de linkernierarterie werd een pathologisch vergrote lymfeklier gezien. De skeletscintigrafie toonde geen ossale metastasen.

$\mathrm{Na}$ multidisciplinair overleg werd besloten tot het verrichten van een exploratieve laparotomie. Bij exploratie werd een geel/grijs tumorproces gezien, dat dermate vergroeid was met zijn omgeving dat resectie met microscopisch vrije snijvlakken onmogelijk leek. Derhalve werden enkele naaldbiopten genomen voor een classificerende diagnose. Histologisch onderzoek toonde dat er sprake was van een diffuus grootcellig B-cellymfoom (DLBCL). Bij revisie van de CT-scan werd er gesproken over een hypovasculaire, diffuus groeiende tumor die slecht aankleurt in de arteriële contrastfase. Dit is atypisch voor een RCC of een UCC. Verder was er sprake van een diffuse laesie langs de mesenteriale vaatas, waarbij een jejunumlis betrokken lijkt te zijn, welke circumferentieel verdikt was. Dit zou kunnen passen bij de groeiwijze van een lymfoom. Postoperatief verslechterde de conditie van de patiënt dermate, dat hij op de vierde postoperatieve dag kwam te overlijden.

\section{Discussie}

\section{Primair renale lymfomen}

Deze casus beschrijft een patiënt met een zeldzame niertumor, die primair slechts in minder dan $1 \%$ van de solide nierafwijkingen voorkomt [2]. Men spreekt van een primair renaal lymfoom als de eerste manifestatie van een lymfoom in de nieren wordt gevonden of als de laesie zich beperkt tot de nieren [3]. Een primair renaal lymfoom kan zich presenteren als een solitaire massa (10-20\%), maar vaker ziet men multipele afwijkingen $(60 \%)$ en meestal komen die bilateraal voor [4]. Lymfomen manifesteren zich zelden primair in de nier, maar secundaire betrokkenheid wordt frequent waargenomen [5].

Er zijn meer dan 40 soorten B-cellymfomen, waarvan het DLBCL met 30-35\% het meest frequent voorkomt [6]. Het primair renaal lymfoom betreft meestal een DLBCL en treft patiënten met een gemiddelde leeftijd van 66 jaar [3]. In tegenstelling tot de operatieve behandeling van het RCC en UCC, bestaat de behandeling van een renaal lymfoom uit een combinatie van chemotherapie en immunotherapie.

Radiologische kenmerken, zoals hypovasculariteit, diffuse groei, slechte aankleuring na intraveneuze contrasttoediening en het ontbreken van calcificaties, zijn atypisch voor een renaalcelcarcinoom en kunnen in de richting van een lymfoom wijzen. Gezien de zeldzaamheid van een renaal lymfoom, worden deze radiologische kenmerken vaak niet herkend. Het tijdig opnemen van een lymfoom in de differentiaaldiagnose van een niertumor op beeldvorming kan reden zijn voor het verrichten van een biopsie. Hiermee kan een operatie worden voorkomen en kan behandeling worden gestart met chemo-immunotherapie. In dit artikel worden de radiologische kenmerken van een renaal lymfoom en de diagnostische overwegingen besproken.

\section{Prognose en behandeling}

Een DLBCL kenmerkt zich door een snel ziekteverloop en meer dan $50 \%$ van de patiënten presenteert zich met uitgebreide ziekte. Sinds 40 jaar wordt de basis van de behandeling gevormd door een combinatie van cyclofos- 
famide, doxorubicine, vincristine en prednisolon (CHOP), waar sinds 15 jaar het monoclonale anti-CD20-antilichaam rituximab aan is toegevoegd [7]. Initiële responsen treden snel op met afname van tumorgrootte binnen enkele dagen. In de weinig beschikbare, oudere literatuur wordt een mediane overleving van een primair renaal lymfoom van minder dan een jaar gerapporteerd. In de recente publicaties vindt men, waarschijnlijk dankzij de toevoeging van rituximab, een betere overleving [2, 8].

De prognose is slechter bij oudere patiënten ( $>60$ jaar), patiënten met een slechte algehele conditie, met uitgebreide ziekte (stadium III-IV), uitgebreide extranodale groei of met een hoog LDH-gehalte in het bloed [9]. Onze patiënt is ouder dan 60 jaar met een verhoogde LDH-spiegel, die bij eerste presentatie nog in goede conditie verkeerde. Zijn conditie verslechterde postoperatief echter progressief en er was een delay van een aantal weken geweest alvorens de diagnose werd gesteld middels histologisch onderzoek. Dit is kostbaar tijdsverlies als een in opzet curatieve behandeling gestart had kunnen worden.

\section{Differentiaaldiagnostische overwegingen}

Het is een diagnostische uitdaging om een renaal lymfoom te differentiëren van andere renale massa's. Vooral als het gaat om een unilaterale presentatie van een primair lymfoom, dat klinisch en radiologisch veel gelijkenissen met het RCC vertoont. Uit de literatuur blijkt dat de diagnose vaak pas gesteld wordt na een nefrectomie [3, 10]. Dimopoulos et al. vonden een renaal lymfoom bij zes van de 210 patiënten met radiologische verdenking op een renaalcelcarcinoom. Bij vijf van de zes patiënten gebeurde dit na een nefrectomie [3]. Ferry et al. stelden de diagnose in acht van de negen unilaterale renale lymfomen ook pas na een nefrectomie [10]. Er zijn echter kenmerken van de tumor op een CT-scan, die een lymfoom hoger in de differentiaaldiagnose kunnen plaatsen. Opvallend op de CTscan in onze casus is de slechte aankleuring van de tumor in de contrastfase. UCC's en RCC's zijn meestal hypervasculair en nemen goed contrast op. Renale lymfomen zijn daarentegen vaak hypovasculaire massa's met minimale contrastopname en laten een relatief homogeen beeld zien (zie fig. 1). Ondanks de grillige invasieve groeiwijze, groeien deze lymfomen zelden bloedvaten binnen en, in tegenstelling tot bij renaalcelcarcinomen, ziet men bij lymfomen zelden calcificaties [4]. Het hypovasculaire karakter van de tumor in onze casus is atypisch voor een klassiek heldercellig renaalcelcarcinoom, maar sluit een RCC niet uit. Er zijn niet-heldercellige vormen van een RCC, zoals een chromofoob of papillair RCC, die eenzelfde hypovasculair beeld kunnen laten zien. Ook kan een hypovasculair beeld op een CT-scan nog wijzen op een sarcoom of een metastase van een onbekende primaire tumor.
Een percutane biopsie van laesies van de nier wordt niet frequent verricht, omdat het aldus verkregen biopt zelden tot klinische consequenties leidt. Bovendien bestaat er een theoretisch risico dat er tumorspill in het biopsiekanaal optreedt [11]. Echter, met de steeds verbeterde naalden (tru-cut biopsy) is het risico hierop erg klein. Als een tumorproces irresectabel of reeds gemetastaseerd is, is een biopt noodzakelijk om een classificerende diagnose te krijgen waarop de systemische therapie gebaseerd kan worden. Daarnaast kunnen biopten overwogen worden indien een nierlaesie niet de typische radiologische kenmerken van een renaalcelcarcinoom vertoont en er twijfel is over de primaire behandeling. Als het atypische CT-beeld bij onze patiënt eerder was herkend als een mogelijk lymfoom, hadden biopten eerder tot de diagnose geleid en was de patiënt een laparotomie bespaard gebleven. Mogelijk had hij dan nog wel een bijdragende behandeling met chemo-immunotherapie kunnen ondergaan.

\section{Conclusie}

Kennis van de typische en atypische kenmerken van renale maligniteiten kan bijdragen aan snellere detectie van het primair renaal lymfoom. Vooral hypovasculaire renale tumoren op de CT-scan, zouden de verdenking op een renaal lymfoom moeten doen rijzen. Als er twijfel rijst over de diagnose en de primaire behandeling, zou een biopt de volgende stap moeten zijn. Hoe sneller de diagnose is gesteld, hoe sneller kan worden gestart met de juiste therapie.

Open Access This article is distributed under the terms of the Creative Commons Attribution 4.0 International License (http:// creativecommons.org/licenses/by/4.0/), which permits unrestricted use, distribution, and reproduction in any medium, provided you give appropriate credit to the original author(s) and the source, provide a link to the Creative Commons license, and indicate if changes were made.

\section{Referenties}

1. Wu PY, Lin SF, Wu PH, et al. Multiple hypovascular tumors in kidney: a rare case report and differential diagnosis. Case Rep Med. 2013;2013:1-4.

2. Vázquez Alonso F, Sánchez Ramos C, Vicente Prados FJ, et al. Primary renal lymphoma: report of three new cases and literature review. Arch Esp Urol. 2009;62(6):461-5.

3. Dimopoulos MA, Moulopoulos LA, Costantinides C, Deliveliotis C, Panazopoulos D, Dimopoulos C. Primary renal lymphoma: a clinical and radiological study. J Urol. 1996;155(6):1865-7.

4. Urban BA, Fishman EK. Renal lymphoma: CT patterns with emphasis on helical CT. Radiographics. 2000;20(1):197-212.

5. Richmond J, Sherman RS, Diamond HD, Craver LF. Renal lesions associated with malignant lymphomas. Am J Med. 1962;32: 184-207. 
6. Swerdlow SH, Campo E, Harris NL. et al. WHO Classification of Tumours of Haematopoietic and Lymphoid Tissues, 4th. ed. Lyon: IARC press; 2008

7. Tilly H, Vitolo U, Walewski J, et al. Diffuse large B-cell lymphoma (DLBCL): ESMO Clinical Practice Guidelines for diagnosis, treatment and follow-up. Ann Oncol. 2012;23(Suppl 7):vii78-82.

8. Pahwa M, Gupta N, Tyagi V, Chadha S. Primary renal lymphoma: is prognosis really that bad? Saudi J Kidney Dis Transpl. 2013;24(4):816-7.

9. Sehn LH, Berry B, Chhanabhai M, et al. The revised International Prognostic Index (R-IPI) is a better predictor of outcome than the standard IPI for patients with diffuse large B-cell lymphoma treated with R-CHOP. Blood. 2007;109(5):1857-61.
10. Ferry JA, Harris NL, Papanicolaou N, Young RH. Lymphoma of the kidney. A report of 11 cases. Am J Surg Pathol. 1995;19(2):134-44. 11. Mullins JK, Rodriguez R. Renal cell carcinoma seeding of a percutaneous biopsy tract. Can Urol Assoc J. 2013;7(3-4):E176-9.

drs. Maud A. S. Weerink semi-arts urologie, thans anios intensive care Medisch Spectrum Twente

drs. Marcel Nijland internist-hematoloog

prof. dr. Igle J. de Jong uroloog

dr. Annemarie Leliveld uroloog 